Trinity College

Trinity College Digital Repository

Faculty Scholarship

$1-1-2020$

Virtuous globalization, the three-zeros policy, and China's choice

Guanzhong James Wen

Trinity College Hartford

Follow this and additional works at: https://digitalrepository.trincoll.edu/facpub

Part of the Economics Commons 


\section{Journal of Chinese Economic and Business Studies}

\section{Virtuous globalization, the three-zeros policy, and China's choice}

\section{Guanzhong James Wen}

To cite this article: Guanzhong James Wen (2020): Virtuous globalization, the threezeros policy, and China's choice, Journal of Chinese Economic and Business Studies, DOI: 10.1080/14765284.2020.1862637

To link to this article: https://doi.org/10.1080/14765284.2020.1862637

曲 Published online: 30 Dec 2020.

Submit your article to this journal $\asymp$

III Article views: 64

Q View related articles $\asymp$

View Crossmark data 


\title{
Virtuous globalization, the three-zeros policy, and China's choice
}

\author{
Guanzhong James Wen \\ Department of Economics, Trinity College, Hartford, CT, USA
}

\begin{abstract}
Economic globalization is generally desirable and beneficial to a great extent, but not necessarily virtuous. Modern history has proven time and again that economic globalization may go astray if rivalry among big powers are not coordinated and regulated in a timely manner. Thorny issues arise inevitably when globalization involves big economies such as China, whose resource allocation mechanisms deviate significantly from that of a typical market economy. This paper will focus on: 1) What is virtuous globalization? 2) Why should big powers adopt the goal of three-zeros (zero tariff, zero barrier, and zero subsidy) as a necessary condition for achieving the goal of virtuous globalization? 3) Why should China in particular set a leading example to adopt and implement this policy to make a real contribution to the building of global institutions that are conducive to virtuous globalization as well as its domestic economic reforms.
\end{abstract}

\section{ARTICLE HISTORY}

Received 6 November 2020 Accepted 8 December 2020

\section{KEYWORDS}

Globalization; Chinese economic system; China's industrial policy; three zero policy

\section{Introduction}

Protectionism is on the rise. According to an article from BDI (2019), 'Since October 2008, the WTO has regularly recorded new protectionist measures taken by its members. Between October 2008 and October 2019, WTO members introduced a total of 1.654 trade-restrictive measures. From May to October 2019, the G20 countries alone took restrictive measures affecting an estimated trade volume of 460,4 billion U.S. dollars. This is the second highest volume since the start of this calculation in 2012. Two periods previous from May to October 2018, the affected trade volume of 480.9 billion U.S. dollars was even higher.'

Nations are increasingly on the alert on each other's trade and investment policies. The UK has voted to exit from the EU to seek its own path to future. The Trump administration has been complaining that the US is not fairly treated in its trade relationships with Europe, Canada, Mexico, Japan, and particularly China among others. India has not only decided not to join the RCEP at the last minute, but also tightened its imports from China, and prohibited the use of many of its APPs. Rivalry between the US and China are escalating. As the largest economy, the US is now emphasizing reciprocity and balance of trade and imposing high tariffs on imports from China. As the second largest economy, 
China has endorsed an industrial policy on a large scale along a statist road, aiming to surpass the US in terms of economy and technology in near future.

The sudden breakout of the Covid-19 pandemic has been seriously threatening lives and disrupting the international division of labor chain (IDOLC), further fueling frictions among nations. Frightened by the rapid spread of the viciously infectious virus, some have gone so far as to advocate that national security and independence should be above everything else. The long-discussed reforms within the WTO has been in stalemate since the collapse of Doha Round. Anti-globalization seemingly becomes a trend in many places. Apparently, globalization is at a crossroad. At this critical moment, it might be useful to take a brief look at the reason why globalization was once favored by so many nations in the last few decades, why it is now facing many strong backlashes, and how to make it back on the right track.

Although international trade could be traced back thousands of years, not until the great geographical discovery age when new maritime routes finally brought all the continents together did the transcontinental trade start to flourish. Merchants bought goods from places where they were cheap, shipped them to faraway places where they were expensive, making a profit from the price differences. This type of profit is called gains from trade.

Gradually, not only merchants but also governments came to realize that, if allowing resources to flow freely across national borders, and production to be conducted in places where there were favorable institutions and sound infrastructures, the same amount of resources can bring about much higher values. Thus, the international division of labor emerged in the form of multinational corporations among nations many of them once believed in self-reliance and close-door policy, to better exhaust the gains from trade. As more and more nations officially got involved by adopting an open-door policy, this phenomenon is named globalization. The global trade values often grew faster than the total values of global production, indicating that the division of labor and trade were deepening and widening faster than the growth of global production.

According to Market Business News (2020), 'Economic globalization refers to the mobility of people, capital, technology, goods and services internationally. It is also about how integrated countries are in the global economy. It refers to how interdependent different countries and regions have become across the world.'

The above definition gives a good description of what is economic globalization. However, it does not answer the many follow-up questions: Why is the driving force behind economic globalization so strong that nations came out of autarky, a status where they could have better preserved their seemingly well cherished identities, languages, cultures, political systems, and religions to engage in the international division of labor and trade? What are the ultimate sources of gains that are large enough to induce nations to overcome their fear and hesitation and accept the cost that the international division of labor and trade inevitably incurs? What are the main differences of virtuous vs vicious globalization? Why should big powers adopt the goal of three-zeros (zero tariff, zero barrier, and zero subsidy) as a necessary condition for a virtuous globalization? Why should China in particular set a leading example to adopt and implement this policy if it wants to contribute to virtuous globalization.

The organization of this article is as follows. Section 2 discusses the two types of gains from trade as the ultimate driving force of globalization. This section also attempts to 
define what is virtuous vs vicious globalization. Section 3 discusses lessons from the history of globalization. Section 4 discusses why Industrial policy pursued by big powers will inevitably lead to vicious globalization and why is the policy of three zeros one of the necessary conditions for a virtuous globalization. Section 5 demonstrates why the accommodating capacity of the IDOLC has made the industry policy not only an anachronism, but also unnecessary for the goal of virtuous globalization today. Section 6 discusses why globalization is at a crossroad if big nations such as China pursues a statist path to its rise. Section 7 discusses why by first adopting the three zeros policy, China can mitigate concerns among other nations and help avoid the path of vicious globalization.

\section{Two sources of gains from trade as the ultimate driving force of globalization}

\subsection{Sources of gains from trade}

Two basic facts are worthy noticing. First, the geographical distribution of resources throughout the planet is extremely uneven. Second, the distribution of human race is equally uneven across sovereign states. These two facts result in extremely uneven distribution of per capita resources across nations. Take China for an example. Almost every important per capita resource index of hers, such as arable land, fresh water, forests, petroleum, natural gas, iron ore, etc., is well below the world average, except for a few items such as coal and rare earths. It is obvious that any nation that chooses to live in autarky will find it impossible to achieve a standard of living comparable to that of nations that choose to trade.

Economically, there are two ultimate sources of gains from globalization. The first one is comparative advantage (CA), put forward by Ricardo. Heckscher and Ohlin, two Nobel laureates, provide a more profound explanation of what comparative advantage is. According to them, a nation gains if it exports products that intensively uses its relatively abundant, thus, cheaper factors of production, imports products that intensively uses its relatively scarce, thus, more expensive factors. Therefore, a nation's comparative advantage is based on its relatively cheaper input because it is relatively abundant. Thus, even a least developed country can benefit from participating in this type of trade because of the low threshold, as this type of trade is not based on a nation's absolute advantage, As Adam Smith believed.

The second ultimate source of gains from globalization comes from increasing returns to scale (IRS). Krugman, a Nobel laureate too, has most profoundly expounded how nations, especially large ones, can explore this source of gains. The essence of IRS is based on a simple fact that, for industries such as aircrafts, ship buildings, automobiles, semiconductors, etc., that incur high fixed costs. They can reduce average costs dramatically by scaling up their total output. In Section 4, I will explain that IRS, while bringing about huge gains to nations, can also be a trap for the goal of achieving virtuous globalization if not regulated and coordinated among big nations in time.

In this article, virtuous globalization is defined as open, inclusive, efficient in the sense that it is based on the deepening and widening international division of labor and trade, shaped and determined by an underlying market mechanism that allocates resources across the world, at the same time it is well-governed by international institutes, 
environmentally and ecologically friendly, providing equal footing and opportunities to all the participating nations, resulting in a highly integrated, mutually interdependent, and sharing human community of nations with harmony, lasting peace, and sustainable prosperity.

\subsection{Definitions: virtuous vs vicious globalization}

Globalization is not necessarily virtuous. On the contrary, it is full of pitfalls. For instance, when IRS is present but abused, big nations might be tempted, as once some of them were, and still are the case, to use their relatively big home market as a leverage to exact benefit in a statist and nationalistic way at the expense of other nations, especially the small and medium-sized nations. This selfish and nationalistic behavior of some big powers inevitably leads to rivalry among all the big powers, resulting in the reverse of globalization or an even worse situation. This article will focus on this in what follows.

Vicious globalization is just the opposite of virtuous globalization when the participating nations are not homogeneous in their resources allocating mechanisms. For this reason, there are frictions and confrontations between different economic systems. Globalization is inevitably not conducted in an open, inclusive environment. It is also not efficient in the sense that it is not based on the deepening and widening international division of labor and trade, shaped and determined by an underlying and unifying market mechanism that allocates resources across the world. The segregated world markets, high tariff rates, non-tariff barriers, subsidies from governments, and distorted exchange rates result in shallowing and shrinking IDOLC, and in reduced gains from CA and IRS. Not only is this situation unfair to small and medium-sized nations, environmentally and ecologically unfriendly, but also prompts fierce rivalry, low integration, and low interdependence among participating nations, especially among big nations, resulting in heightened hostility, fragile peace, and unsustainable prosperity.

\section{Lessons from history}

\subsection{Under the Pax Britannica}

The essence of globalization is to promote the opening of countries for the free flow of goods and services at a lower stage of globalization, and for the flow of factors of production at a higher stage of globalization. Throughout the whole $19^{\text {th }}$ century, Britain was the leader in globalization for the following two reasons. Britain, as the most developed economy at the time and a firm believer in the tenets of open market and free trade, promoted and installed a lot of rules and regulations that were conducive to international division of labor and trade. Thus, it made a great institutional contribution to the governance of globalization.

Britain also drew admiration from the whole world by advancing technological progress rapidly. It was the birthplace of Industrial Revolution and a leading force in invention and innovation since then for a long time. Standing at the forefront, it had nowhere to turn to for inspiration and imitation but to be original and creative. It succeeded remarkably in constantly pushing out new products, each of which represented something unprecedented technically in human history. This achievement not only made its 
economy vibrant and powerful, but also made its leadership widely and convincingly accepted.

However, the global governance under the Pax Britannica contained a fatal mistake that was the acceptance of colonialism. This led globalization fragile and unsustainable. The latecomers, by using the same law of the jungle, demanded to have their own colonies. The world peace became extremely unstable when there were no longer unoccupied territories for the latecomers to grab. They had nowhere to turn to but to challenge the incumbent colonial powers. Germany and Japan acted exactly in this way. Using nationalistic economic theories, they embarked a militarist and fascist road to pursue their own 'breathing room', i.e., their own colonies by attacking Britain and its allies.

During this period, economic theories, such as mercantilism, infant industry, and centrally planning, emerged and flourished, sent globalization astray to varying degrees. In the first half of the $20^{\text {th }}$ century, vicious rivalry propelled by these wrong theories among great powers brought globalization to a standstill twice because of the two bloody World Wars.

\subsection{Globalization under the Pax Americana}

The new post-war international order promoted by the US and its allies inherited a lot from the rules and regulations emerged and evolved under the Pax Britannica. This is because the US was already converted into a firm believer in free trade and open market. However, drawing on the bloody lessons of the two World Wars, the international governance under the Pax America has the abolition of colonialism at its core. For this purpose, the United Nations, the World Bank, and the International Monetary Fund were created to coordinate issues and frictions among all the nations, particularly those among the big powers, and those that were scheduled to become independent from the yoke of colonialization.

Among all the institutions that the U.S. helped form, the GATT, established in 1947, is most relevant here. Its Preamble (The Preamble of GATT 1947) states:

"Recognizing that their relations in the field of trade and economic endeavor should be conducted with a view to raising standards of living, ensuring full employment and a large and steadily growing volume of real income and effective demand, developing the full use of the resources of the world and expanding the production and exchange of goods,

"Being desirous of contributing to these objectives by entering into reciprocal and mutually advantageous arrangements directed to the substantial reduction of tariffs and other barriers to trade and to the elimination of discriminatory treatment in international commerce."

The Preamble of the GATT requires all the contracting countries gradually reduce tariffs, remove barriers and reduce state subsidies, making national markets more open to allow the free flow of factors of production, resources, and products in response to changes in prices across borders to realize their higher values.

If all the nations agree to open their markets and trade with each other, then they no longer have reason to compete for colonies or exclusive spheres of influence on the battlefields to gain so-called breathing rooms. They only need to compete peacefully at the world markets to obtain what they need, and to sell what they produce. Here the 
market prices play a decisive role in helping a firm to find its comparative advantage. For given input and output prices, the size of profit margin will lead a firm to find its position in the IDOLC. Not only firms can share the gains from CA and IRS, the highly interdependent international economic structures also make former enemies close allies.

As Britain once did, the United States also contributes to the leadership of this round of globalization enormously in two key fields. First, it promotes the free market economy worldwide by almost unilaterally opening its vast market to give other nations the first push. In addition, it also provided aid to first help Western Europe, including Germany, once its enemy, to rebuild prosperity from ashes. Then in East Asia, the U.S. helped Japan, another former enemy, emerge from ashes to quickly become the second-largest economy until about a decade ago when Japan was overtaken by China. The peace and prosperity of the four dragons (South Korea, Taiwan, Hong Kong, and Singapore) in East Asia would have also been impossible had the post-war order not been established and defended by the United States.

In terms of technical progress, the US has been a leading center for research and invention even before it took over the leadership of globalization from Britain. Different from Britain towards the later period of its global leadership, the US is still maintaining a big edge over other nations today, and expectedly do so in the foreseeable future in this field. The capacity of US in high tech makes its leadership in globalization convincing and widely acceptable in the world. US has been creating rooms for latecomers as its technical breakthroughs send its industries into new frontiers, deepening and extending the IDOLC constantly.

\subsection{Lessons from Comecon}

The Soviet Union and its allies recognized the great potential gains that international division of labor and trade could generate. They were initially part of the GATT negotiations. However, the fatal mistake they committed was to reject the market mechanism as the most effective way to exhaust these gains. Instead, they chose the centrally planning system to allocate their resources. This fundamental difference in addition to other more political and ideological ones led to the split of Soviet block from the West. The cold war began in 1949. The Soviet Union formed the 'Council for Mutual Economic Assistance (Comecon)' within its block to explore the gains from division of labor and trade among members.

Under the Soviet model, factor markets were banned, enterprises were basically state owned, and resources were allocated by central planning committees. Since there were no price signals generated by a market mechanism, enterprises were unable to find out their true comparative advantage, the role that each member should play in the division of labor within the Comecon had to be assigned by the Soviet Union with poorly grounded economic rationality. As a result, the efficiency was low, so were the gains from this type of division of labor. The collapse of the Soviet Union in the early 1990s finally brought an end to the Comecon.

Compared with the success of GATT, the main lesson from Comecon is that good will for international division of labor and trade is far from being enough and doomed to fail if participating nations do not base the division of labor on a market mechanism. Without this mechanism as the decisive allocator of resources, each participating nation's role in 
the division of labor can only be artificially assigned, thus, violating the law of comparative advantage.

The two rounds of globalization under the Pax Britannica and the still unfolding Pax Americana have some similarities. Both benefit from their respective leaders in the following fields: 1) recognizing and promoting the irreplaceable function of market mechanism in resource allocation globally so that the gains from international division of labor and trade can be explored efficiently and continuously; 2) being able to enter new areas of economic activities by advancing technical invention and innovation and deepening and widening the division of labor chain. As the two leaders escalate along the rungs of chain, rooms are left for latecomers to fill. This is especially true under the Pax Americana when all the former colonies won independence and the developed nations can no longer grab exclusive spheres of influence to dump their surpluses.

\section{Why industrial policy by big powers will lead to vicious globalization}

\subsection{Why is industrial policy a major pitfall for virtuous globalization}

Unfortunately, on the road to virtuous globalization, there are full of pitfalls. The followings are just a few:

1) Unwilling to share the gains from IRS out of a nationalistic motive under the name of industrial policy.

2) Single-mindedness in attempting at curve overtaking without giving thought to the adjustment costs borne by other countries.

3) After joining WTO with lower criteria, refusing to complete market-oriented reforms, or even retreat.

4) Compete for leadership over the model of globalization without deep understanding of the essence of market mechanism.

For the sake of brevity, this article will only focus on the first one listed above, i.e., the possible negative effect of IRS. This strategy was first promoted theoretically by List (1841), a German economist of the $19^{\text {th }}$ century. List argued that as a latecomer, Germany should completely abolish all the forms of local tariffs to unify the otherwise fragmented domestic markets. Once the capacity of domestic markets was maximized, Germany should impose tariffs on imports from outside to protect the growth of domestic infant industries. However, this strategy cannot succeed without the help from the government, because only the government can erect tariffs and build up other protective barriers, including the information barriers, to shield domestic industries and commerce from foreign competition. Therefore, to pursue an industrial policy is inevitably to follow a statist road. List theory of infant industry thus paved a statist road that Germany, as a latecomer, indeed pursued in the later $19^{\text {th }}$ century and early $20^{\text {th }}$ century with an aim to rival with Britain for the domination of Europe, and then the world. This rivalry between Britain and Germany led to world-wide wars twice in the last century.

Along this line of thought, a big nation can artificially cultivate the growth of a chosen firm with IRS by closing its domestic markets through prohibitively high tariffs, in addition to other trade barriers such as blockade of information, distorted exchange rate, and heavy subsidies from the state. Once it is shielded from foreign competition, the chosen 
firm can quickly and smoothly reduce the average costs by scaling up its production. As soon as the average cost drops low enough and becomes competitive internationally, the firm could then go to the world market and easily beat all the other firms in this industry.

The nation can repeat the same strategy to nurture other industries with IRS, and if not being interrupted or regulated, the nation can eventually achieve economic dominance globally at the expense of other big nations that remain open. Such statist way to nurture a nation's infant industries is now termed industrial policy. It leads inevitably to high tariffs, manipulated exchange rate, heavy government subsidies, and other governmenterected trade barriers. Sooner or later, this practice, if not stopped timely, will invite imitation by other great powers, resulting in segregated world markets, high tariff rates, distorted exchange rates, shallowing and shrinking IDOLC, and reduced gains from CA and IRS.

Such rivalry among big powers puts small and medium-sized nations in a particularly unfavorable position. By closing their respective domestic markets, not only do the big powers de facto exclude each other from own markets, but also denies small and medium-sized nations from participating to a great extent in the IDOLC. The reason is as follows. Typically, firms in these types of industries with IRS produce complex products, requiring hundreds, thousands, or even tens of thousands of different parts and components. These parts and components require different level of intensity of factors of production, providing rich opportunities for nations with different comparative advantages embedded in their different compositions of factor endowment. If the home markets of a big country is open, its firms will choose to only produce those parts and components that they do have comparative advantage and leave the rest of parts and components to other nations, including the small and medium-sized nations.

\subsection{Why is three zero policy a necessary condition for virtuous globalization}

This situation is especially beneficial to the latter. They otherwise will be unable to share the gains from the IRS because of relatively smaller domestic markets. In an open market situation, they still can have access to the gains from IRS by specializing in some parts and components that they have comparative advantages. In this way, all the participants, especially the small and medium-sized nations, can share both the gains from CA and from IRS. This should be the essence of a virtuous globalization. Thus, to induce globalization to take a path of virtuous one, tariff, non-tariff barriers, subsidies that a nation, especially a big nation, is permitted within the WTO to impose should be zero. This three zeros policy should be a necessary condition for a virtuous globalization.

If, instead, a big nation refuses to fully open its market by imposing high tariffs, erecting non-tariff barriers, and subsidizing its chosen firms, then its sincerity to a virtuous globalization is dubious, or even suspicious. It can hardly defend itself if other nations accuse it to attempt to achieve economic dominance in the world market with a very narrow nationalistic and selfish agenda. By denying the other nations, especially the small and medium-sized nations, opportunities in sharing the gains from IRS, even morally it can hardly defend itself. If all the big nations behave in this way, the globalization cannot continue to be conducted in an open, peaceful, inclusive, sharing, efficient, integrated, interdependent environment with equal opportunities to all the participating nations, as a virtuous globalization requires. In worst 
case, the rivalry among big nations might escalate into confrontation and wars. This type of globalization can only be a vicious one. Therefore, the three zero policy is a necessary condition for a virtuous globalization. All the participants, especially the big nations, should set this policy as their goal as they are pursuing a virtuous globalization. Only the developing small and medium-sized nations can adopt this goal at a slower pace.

\section{Accommodating capacity of the current international order and the challenges}

\subsection{Accommodating capacity and the resultant peace}

During the early rounds of globalization when the world was divided up into rival powers on one side and colonies and spheres of influence on the other side, it might be justified to use the theory of infant industry by some latecomers, as advocated by List, to nurture and develop their national economies along a statist line on the ground that the world market was so segregated, fragmented, and even exclusive to them. However, it is an anachronism to pursue such a statist line today in an era of globalization for the following reasons.

First, the current international order established after the World War II has long abolished all types of colonies and prohibited nations to expand territory by means of wars. At the same time, this order has been promoting international division of labor and free trade among all the nations that are willing to open their markets and cooperate with the rest of the world. As a result, all the resources of the world are available at the international markets. Nations can compete for their acquisition peacefully at the markets after paying prices agreed upon mutually instead of fighting for them on the battlegrounds.

Many initially did not believe that after abolishing colonies and spheres of influence, big powers could survive, let alone thrive. However, the success under the GATT eloquently proves how wrong these people were. Big powers can have lasting prosperity without colonies and spheres of influence. For those who once predicted that the metropolitan nations would soon wither after losing their colonies, must be puzzled by the fact that they became more vibrant and prosperous instead, once they got rid of their colonial burdens. An important reason is, they have been able to acquire the otherwise lost gains from CA and IRS through international division of labor and trade instead of confrontation and rivalry under the Pax Britannica. This chain, through deepening and widening, has greatly expanded the breathing rooms for all the nations, especially for the big powers, without provoking wars.

Second, the current IDOLC has proven to have great accommodating capacity. Today this chain has reached an unprecedented depth and width, at the same exhibited an amazing elasticity. As mentioned above, under the GATT it first accommodated peacefully the rise of all the big European powers, including Germany, the most dynamic nation in Europe. Then it did the same for the rise of Japan, another dynamic nation with few resources but high density of population. Since China's accession into the WTO in 2001, this chain has been accommodating peacefully this giant. Despite the fact that its size and population pale the combination of Germany and Japan, China overtook all of Europe's 
developed countries successively, then overtook Japan soon after that to become the world's second-largest economy within ten years without disrupting fundamentally the current international order.

This phenomenal peaceful growth of China could not occur by a pure accident. In the absence of the opportunities presented by the WTO, it is inconceivable that China could achieve this big leap forward peacefully. More specifically, without being accepted into the long IDOLC so that it could have its otherwise long idled resources utilized in a much more efficient way, and reap the huge gains from CA and IRS, the gigantic leap, achieved by China, that we have witnessed could hardly be so swift and so peaceful. Hence, there is no reason to believe that the current international order, as is embodied in the IDOLC, has fundamental flaws in accommodating big latecomers such as China now, and India, Brazil, Russia, and South Africa in the future.

Third, however, unlike Germany and Japan that has abandoned a statist line of development, and accepted a market system as their main resource allocation mechanism under the GATT, either willingly or under the pressure from the US, China is still obsessed with using state power to allocate resources. Those who are anticipating China to open its market sooner and wider are now deeply disappointed. China is taking a different path from Germany and Japan under the current international order by making it known to the whole world that it will pursue an industrial policy on a national scale, as will be discussed shortly.

\subsection{Precondition for smooth accommodation}

One of the reasons that Germany and Japan under the GATT could climb up along the rungs of the IDOLC successively and successfully without disrupting the existing world order was the leading role played by the US. The latter opened its huge market almost unilaterally soon after the end of the World War II, setting a convincing example for others to follow suit. As the war-stricken nations in Europe and East Asia gradually recovered from ruins, they opened their markets in turn under the GATT. The trilateral openness among the US, Europe, and Japan has provided strong and positive stimuli in the form of rapidly expanding markets to accelerate the successful commercialization of inventions and innovations and enable their industries to escalate into new fields. As the IDOLC constantly deepens and widens into new frontiers, it leaves vacancies behind for other latecomers to fill in in a peaceful way. For the last 20 years or so, China has particularly benefited from the accommodating capacity of this chain. In return, the international community, especially the US, Europe and Japan are expecting China to behave in the same way by further opening its market and integrating deeper into the world economy as its economy grows and becomes more complex and diversified.

\subsection{The three-zero policy as a precondition for virtuous globalization}

After reviewing the facts above, one can see that there are preconditions for this chain to continue to deepen and widen for the small and medium-sized nations to be able to share the gains from CA and IRS. First, the big nations must open their markets early enough to show their sincerity in integrating their economy into the world system. Otherwise, interest groups will grow too strong to be dismantled later. Second, all the nations 
involved in this IDOLC must keep their tariff rates low, so commercially it is profitable to use the IDOLC to produce products that need many different parts and components, as mentioned above. This is also why both the GATT and the WTO pushed and is still pushing members to periodically reduce their tariffs, barriers, and subsidies. Implicitly both institutes take the policy of three-zeros as a long-terms goal for globalization. Third, no big nations should be allowed to pursue an industrial policy. This is because an industrial policy cannot succeed without various forms of government intervention such as tariff, trade barriers, and subsidies. Consequently, other big nations will soon retaliate by embarking on their own exclusive paths of industrial policy, resulting in a segregated and fragmented world, and the eventual collapse of the IDOLC. As the chain shrinks or collapse, gains from CA and IRA will be largely lost. Big nations, no matter how big their markets are, will still lose because their own markets cannot be larger than the world market. However, this is particularly a worse situation for the small and medium-sized nations. They will lose most without any doubt.

This is also why this article argued in the above that the policy of three zeros should be a necessary condition for a virtuous globalization. Only in a low or zero tariff environment, the parts and components of a final good can be produced by different nations according to their own comparative advantages, and then shipped to and assembled in one location without incurring prohibitively high tariff cost. In a high tariff world where there is tariff on every part and component, the cumulative tariffs on a final good will make the extension of IDOLC impossible.

In a three-zeros environment, the world will be able to 1) to reduce rivalry by promoting a higher degree of cooperation among big powers, 2) provide vast rooms for growth and development to small and medium-sized nations by offering them roles to play in the industries with IRS. 3) the gains from these industries with IRS can be better exhausted and shared as these industries can reach their full capacity, limited only by the size of the world market. 4) As a result, the interdependence and integration among all the nations, especially the big nations, will be greatly enhanced.

Of course, under the Three-zeros policy, some big nations may be still powerful, but they will be highly dependent and integrated with other nations at the same time. In this case, there are more reasons to expect that the majority nations, most of them are small and medium-sized, will have more leverage over these big powers, a meaningful check and balance that contributes to peace, stability, and cooperation among all the nations. Globalization will more likely evolve along a virtuous path.

\section{A real challenge to virtuous globalization}

\subsection{China's unfinished reform-when to establish functioning factor markets}

China used to be slow in understanding how great the gains from CA and IRS could be, as was reflected in the fact that China even rejected the idea of international division of labor and quitted the Comecon after serving as an observer during the period 1956-1961. Likewise, China was slow in understanding how important a market mechanism was in exploring and exhausting the gains from CA and IRS by wrongly adopting a statist central planning system. China is still slow in realizing that an 
economy without a market mechanism to allocate factors of production is not a real market economy.

Under these circumstances, as a latecomer, it is not realistic for China to imagine that it now has understand everything about the market system, let alone the IDOLC. The best policy for China to follow is to continue to cooperate with the rest of the world, especially the most developed nations. China now is facing a harsh reality. Developed nations, led by the United States, believe that China's current economic system is inherently incompatible with the nature of the WTO. Upon acquiring accession to WTO, China promised to use the grace period of 15 years starting in 2001 to transform its economic system to a true market system. Other nations are still expecting China to honor its own promise as soon as possible.

The defining characteristic of a true market system lies in the presence of three functioning factor markets - land, labor, and capital, plus a free foreign exchange market. However, it is exactly because of the underdevelopment of the factor markets and the foreign exchange market, China's economic system is still fundamentally different from a typical market economy. The interest rate, wage rate, rental rate, and exchange rate, the four most basic prices, are not determined by the forces of supply and demand in China and in the World. It is not a surprise that the US, Europe, and Japan, the most important market economies, have openly rejected China's demand that its status of market economy be recognized in the WTO at the end of the grace period of 15 years. (Griswold and Parks 2019)

A brief discussion is in order. Let's go over the four most fundamental price determination mechanisms. First, as we all know, the interest rate is the price of capital. In a typical market economy, this price should be determined by an independent Central Bank in response to domestic and worldwide market situation. However, in China, this price is only nominally determined by the Central Bank of China. In the reality, the standing committee of the Political Bureau of the CCP issues orders to the Central Bank of China via the State Council to determine the level of basic interest rate.

The wage rate, that is the price of labor, is seriously distorted in China too. As a result of the persistent existence of the discriminatory Hukou system, the migrant workers from rural area do not have equal rights as the local workers in urban areas. While the government allows the peasants to come and to work in urban areas, representing a big progress compared with Mao's era, they still do not have rights to settle down with their families where they work. They have no choice but to leave their spouses and children behind in their native villages. Therefore, the labor market in China are segregated between the local and migrant workers. This duality has seriously suppressed the wages and benefits of the migrant workers, although saved the local government and firm a significant amount of costs that are otherwise required to accommodate the families and children of the migrant workers. This institutional duality has also provoked sharp criticisms from the international communities for unfair competition through suppressed wage rates. (Wen 2014)

The rental rate, which is the price of land, is fundamentally determined by the government, because all the land is either owned by government or owned collectively. However, the collectives are not allowed to trade their own land with anyone but the government. Under this institutional arrangement, the government behaves either like a monopoly, and the land prices are inflated because it is the only seller, or the land prices are seriously suppressed because the government is the only legal buyer. This explains why the housing prices in many urban areas in China are so prohibitively high, often much 
higher than that in a typical high income nation, despite the fact that the per capita income in China is still a small fraction of that we see in a typical developed nation.

The fourth basic price is the exchange rates which are the prices of foreign currencies in terms of home currency. If distorted, this price affects all the prices of imports and exports. Unfortunately, this important price is also distorted, because the Chinese government does not allow Yuan to be traded freely. In other words, Chinese citizens and firms cannot freely convert their money in Renminbi into foreign currencies without permit from the government.

\subsection{The confusing signals sent by China's adoption of industrial policy under the China model}

While China has seen little progress in market-oriented reforms largely due to the delay in the nurturing and growth of the factor markets by further dismantling the remnants of the Central Planning mechanism since 2013, since 2015 the Chinese government decided to take the advantage of its huge market to openly pursue an industrial policy named Made in China, 2025 (hereinafter MIC 2025). According to a study by the Institute for Security and Development Policy (2018), the European Union Chamber of Commerce in China described the MIC 2025 as a regression to 'top-down decision-making'. According to the same study, the U.S. Chamber of Commerce suggested it was a 'strategy to use state resources to alter and create comparative advantage in these sectors on a global scale'. According to Wikipedia (2020), 'The goals of Made in China 2025 include increasing the Chinese-domestic content of core materials to $40 \%$ by 2020 and $70 \%$ by 2025 .' This is a very nationalist line of development against the line of globalization. The same source also reports that the total subsidies going to these Chinese firms from their government amounts to US\$300 billion. No wonder foreign companies fear that they will lose their competitiveness to these heavily subsidized Chinese firms.

The Chinese government is also promoting the so-called China model, which does have many Chinese characteristics. One of the characteristics that stands out most conspicuously is that the Party is sending its representatives to all the enterprises, including some owned by foreigners, to ensure that they are following its guideline. This party-state model makes many in the developed nations very uneasy for the following reasons. First, China is big in terms of its population and sheer size of economy, so it is indeed possible for China to be tempted to exclusively explore the gains from IRS. Second, China's economic system, coming out of centrally planning system only halfway, still has many statist remnants. As pointed above, the underdevelopment of factor markets means that the factors of production such as capital, labor, and land are de facto, or by default, allocated decisively by the government. Third, the party-state model means that ultimately firms in China may not be driven by commercial considerations, but by the needs of the Party, the latter openly claims that it has the right to dominate every facet of the Chinese society. Therefore, there is little doubt that the party-state is ready to execute the MIC 2025 along a statist line. No wonder that many nations, especially the developed nations, react to this prospect very strongly. 


\subsection{Looming clashes}

Europe, Japan, especially the United States, as China's main sources of high tech and largest export markets, have shown their deep disappointment with China's slowness and seriousness in market-oriented reforms. As mentioned before, these three parties have officially rejected China's market economy status in the WTO. Europe and the US have also decided to challenge China's status as a developing country in the WTO. (Baschuk 2019). These two decisions mean that the developed nations can impose heavier tariffs on Chinese exports until they fully accept China as a normal market economy. More recently, the US, Europe and japan had a trilateral meeting and issued a joint statement calling for the further strengthening the list of prohibited industrial subsidies within the legal framework of the WTO. (Office of the US Trade Representative 2020) Apparently, the main target of this joint statement is China, or more specifically, its MIC 2025.

The policy makers in the US have been discussing the possibility of decoupling, either partial or comprehensive, from China. They have introduced a series of measures, including 1) Imposition of tariffs, so that the cost of setting up a factory in China to produce products and then have them sold back to the United States will greatly increase. In response to such policy, firms are considering to move back to the United States, or to a third country; 2) prohibition through Legislation in Congress to export high-tech and dual-use products to China; 3) Restriction on training Chinese senior scientific and technological talents; 4) Restriction on Chinese firms to acquire U.S. companies and imposition of more rigorous accounting requirements for Chinese companies to list on U.S. stock market; 5) Expansion of the G-7 to the G-11 or G-12 to meet the challenges posed by China.

As pointed above, the industrial policy is viewed as a serious anachronism and unnecessary today given the great accommodating capacity of the IDOLC. In the spirit of reciprocity emphasized by the Preamble of the GATT and the WTO, members are entitled to retaliate those members that choose to pursue unilateral interest such as industrial policy. From the discussion above, IRS can indeed induce rivalry among big nations, that, in turn, can lead to vicious globalization. No nation will take the face value of statements or guarantees from a nation that its industrial policy is virtuous and beneficial to all nations, particularly to small and medium-sized nations. Once one big power embarks on this road, others have no choice but to retaliate, or follow suit. Reactions of both will lead to vicious globalization inevitably, an unfortunate development that is in no nation's best interest.

\section{China can help avoid vicious globalization by implementing three-zeros policy first}

As the biggest beneficiary of the most recent round of globalization, in various international venues, China has made it very strongly that it wants to continue to promote globalization despite the fact that the protectionism is on the rise. Based on the experiences of Britain and the United States discussed above, to play a leading role in globalization, a nation must at least be able to serve as 1) a major source of technical inventions and innovations; 2 ) a major source of Institutional innovations that are inspiring to most countries. 
If we use these two yardsticks to measure, China apparently still has some distance to cover before it is ready to assume a leading role to guide globalization for the following reasons. First, different from Britain during its peak time, and the US up to now and in the foreseeable future, the China model is yet to demonstrate how it will inspire inventions and renovations on its own land. China tends to do very well in copying, imitating, and adopting new techniques originated in other nations. It is yet to show originality and creativity of its own as exemplified by Britain and US successively.

Second, the much talked-about China model is at most applicable only to a few transition economies such as Vietnam, Cuba, and potentially North Korea that once implemented or is still implementing a central planning system. The current economic system in China is yet to evolve towards a real market economy. For this reason, the China Model is of little reference for most nations in Asia, Africa, and Latin America that have long adopted the market economic system, let alone for nations in Europe, the United States, and Japan that already have achieved the stage of mature market economies.

However, China is indeed in a unique position to play a leading role to help globalization return to a virtuous path. The globalization will receive a much-needed new momentum if China is willing to adopt and to implement the three-zeros policy. This goal is consistent with the calling that China has been making on various international occasions for building a community of human destiny. Such a calling combined with the adoption of the three-zeros policy will be a clear and convincing signal that Chna can send out to all the nations that it sincerely wants to promote virtuous globalization and to integrate itself into the world system under the existing international order.

This goal is also consistent with the spirit of the decision adopted in 2013 at the $3^{\text {rd }}$ Plenary Session of the $18^{\text {th }}$ Committee of the Chinese Communist Party. (CCP 2013) This decision calls for 'deepening the reform' and 'let the market play the decisive role in allocating resources'. If this is indeed what China really wants, then by accepting the three-zeros goal China will help nurture and develop the factor markets at home. By doing this, China will find itself much more acceptable by other WTO members as fully qualified to acquire the market economy status, a goal that China has been seeking very eagerly and vigorously.

By adopting the Three-zeros policy China will also improve economic relations with the US, Europe, and Japan. The EU and the US have repeatedly declared that their bottom line in trade is three zeros, despite the on-going trade frictions among them. (European Commission 2018) The US is also increasingly turning to the principle of reciprocity to determine how open its market should be to China. All these add together, we can expect that the US and the EU will welcome China's decision that it will follow the three zeros policy. Currently, they are using the principle of reciprocity to imitate China's policies and institutional arrangements to decide how open they should be to China. Of course, if this trend continues, the globalization will be seriously reversed. If China wants to prevent globalization from slipping back, adopting the three zeros policy is the best choice.

China has repeatedly stated that it has no intention of grabbing world leadership, has no intention of subverting the current international order that has made itself the biggest beneficiary, and is determined to continue to promote globalization. Given the fact that globalization will definitely go stray to become a vicious one when the IRS is present but abused, as Section 4 has proven, and Section 5 has proven that the current international order still has unlimited accommodating capacity to allow China to fully grow, there is no 
reason for China to follow such a selfish and unnecessary path and to repeat the same historical mistake once committed by Germany and Japan along a statist line.

China also makes it very strongly that being a developing nation for a long period of time, now it wants to contribute particularly to the growth and development of nations in Asia, Africa, and Latin America. By opening its markets to these nations by making them truly an integral part of the world market, China can win the trust and friendship of these nations. By doing so, China is not seeking to exclusively exhaust, but to willingly share the gains from IRS with the small and medium-sized nations too. This action will be much more convincing than cheap talks but sticking to the industrial policy. As China and the world's economic structure become more intertwined and interdependent, the world's trust in China will increase, suspicion and hostility towards China will lose the ground, globalization will proceed in a virtuous way.

By implementing the three-zeros, China will help deepen and widen the international division of labor so the gains from globalization can be better exhausted. By doing so, China can also avoid partial or comprehensive decoupling, thus avoid the reduction of living standards and the increase in unemployment at home. This result not only will benefit the Chinese people, but also contribute to world peace and prosperity.

After all, if a nation as big as China is serious and sincere about its desire to avoid vicious globalization as it declares repeatedly, it should view its domestic markets as a natural extension of the global market. China should leave its own market as open as the world market is to China. If a big power uses the openness of the world market relentlessly, but views its domestic market as a leverage to exact privileges such as free accessing to foreign patented knowledge and technology, acquiring foreign equity shares, requiring localization of parts and components in joint ventures, and so on, then in fact, it is using its market to obtain extra and undeserving benefits. Such practice is unfair to other big powers that are already fully open, thus no longer in a position to follow suit unless implementing decoupling first. Most damaging effect falls upon the small and medium-sized nations, as by their sizes, they are unable to extract similar benefits and privileges. Therefore, such practice is most unfair to the developing nations that China meant to help.

The future of globalization is primarily in the hands of China and the United States. Globalization is at a critical juncture. China, with the desire to build a community of human destiny, should seize the opportunity and take the courage to set an example by accepting and implementing the goal of three zeros first. By doing so, China may convince more nations to work together to prevent globalization from going back or go estray.

\section{Acknowledgments}

I want to thank two anonymous reviewers for their constructive comments and suggestions. All the remaining errors are mine exclusively.

\section{Disclosure statement}

No potential conflict of interest was reported by the author. 


\section{Notes on contributor}

Guanzhong James Wen received his MA from Fudan University, and PHD from University of Chicago, is now a Professor Emeritus at Trinity College, Hartford, USA.

\section{References}

Baschuk, B. 2019. "Here's What It Means to Be a WTO Developing Country". November 14, Bloomberg. https://www.bloomberg.com/news/articles/2019-11-14/here-s-what-it-means-to-be -a-wto-developing-country-quicktake

BDI. 2019. "Protectionism and Nationalism on the Rise." https://english.bdi.eu/article/news/protec tionism-and-nationalism-on-the-rise/

CCP. 2013. "Decision of the Central Committee of the Communist Party of China on Some Major Issues Concerning Comprehensively Deepening the Reform." http://www.china.org.cn/china/ third_plenary_session/2014-01/16/content_31212602.htm

European Commission. 2018. "Joint U.S.-EU Statement following President Juncker's Visit to the White House." July 25.

GATT. 1947. "The Preamble." https://www.wto.org/english/res_e/booksp_e/gatt_ai_e/preamble_e. pdf

Griswold, D., and D. Parks. 2019. "Is China a Non-Market Economy?" The Bridge, April 2, George Mason University. https://www.mercatus.org/bridge/commentary/china-non-market-economy

Institute for Security and Development Policy. 2018. "Made in China 2025." June. https://isdp.eu/ publication/made-china-2025/

List, F. 1841. The National System of Political Economy. Encyclopedia Britannica. https://www.brit annica.com/biography/Friedrich-List

Market Business News. 2020. "What Is Globalization?" June 6. https://marketbusinessnews.com/ financial-glossary/economic-globalization/

Office of the US Trade Representative. 2020. "Joint Statement of the Trilateral Meeting of the Trade Ministers of the United States, European Union, and Japan." January 14. https://ustr.gov/about-us /policy-offices/press-office/press-releases/2019/may/joint-statement-trilateral-meeting

Wen, G. 2014. "The Hukou and Land Tenure Systems as Two Middle Income Traps-The Case of Modern China." Frontier of Economics in China, co-authored with J. Wu 9 (3): 438-459. 